\title{
Removal of phenol from aqueous solution using rice straw as adsorbent
}

\author{
Nandita Sarker $^{1}$ A. N. M. Fakhruddin ${ }^{1}$ (C)
}

Received: 22 January 2015/Accepted: 11 August 2015/Published online: 28 August 2015

(C) The Author(s) 2015. This article is published with open access at Springerlink.com

\begin{abstract}
Phenol is an environmental pollutant; the present study was conducted to examine the adsorption of phenol by rice straw. For this purpose raw (untreated), physically treated (boiled and dried) and thermally treated (heated at $230{ }^{\circ} \mathrm{C}$ for $3 \mathrm{~h}$ to produce ash) rice straw were selected to determine phenol removal efficiency at different contact times and adsorbent dosages for 1 and $<1 \mathrm{~mm}$ rice straw particles. Residual phenol concentrations were determined by colorimetric method. Highest $84 \%$ of phenol removal was observed for thermally treated $<1 \mathrm{~mm}$ rice straw particle. Equilibrium time was more than four hour. Percentage of removal of phenol increased as the adsorbent dose increase. The removal efficiency increase in the order of: raw rice straw $<$ physically treated $<$ thermally treated (ash) rice straw. Langmuir and Freundlich isotherm was developed for 1 and $<1 \mathrm{~mm}$ particle size of thermally (ash) treated rice straw. Freundlich isotherm best fit the equilibrium data for $1 \mathrm{~mm}$ thermally treated rice straw. The results showed that thermally treated rice straw (ash) can be developed as a potential adsorbent for phenol removal from aqueous solution.
\end{abstract}

Keywords Adsorption - Phenol - Rice straw · Equilibrium · Isotherm

A. N. M. Fakhruddin

a.fakhruddin2@mail.dcu.ie

1 Department of Environmental Sciences, Jahangirnagar University, Savar, Dhaka 1342, Bangladesh

\section{Introduction}

Pollution by phenols is an important environmental issue. Phenolic compounds are common contaminant in wastewater. Phenol is very soluble in water and its presence in water supplies is noticed as bad taste and odor in concentration as low as $5 \mu \mathrm{g} / \mathrm{L}$ (Rengaraj et al. 2002; Aksu 2005). Phenols as a class of organics are similar in structure to the more common herbicides and insecticides in that they are resistant to biodegradation (Mahvi et al. 2004). They are widely used for the commercial production of a wide variety of resins including phenolic resins, which are used as construction materials for automobiles and appliances, epoxy resins and adhesives and polyamides for various applications (Banat et al. 2000; Al-Asheh et al. 2003; Roostaei and Tezel 2004). According to US Environmental Protection Agency (US EPA) phenol constitutes the 11th of the 126 chemicals, which has been designated as priority pollutants. Meanwhile, the World Health Organization (WHO) recommends the permissible phenol concentration in potable waters to $0.001 \mathrm{mg} / \mathrm{L}$ (WHO 1994). They are harmful to organisms even at low concentrations. Human consumption of phenol-contaminated water may lead to protein degeneration, tissue erosion, damaged central nervous system and ultimately harm important organs such as kidney, liver and pancreas (Knop and Pilato 1985). It is therefore necessary to remove phenol completely from wastewater before being discharged into waterways.

Various methods have been used to remove phenol from wastewater including microbial degradation, adsorption, chemical oxidation, incineration, solvent extraction (Aksu 2005), photo-degradation (Wu et al. 2001), flocculation (Ozbelge et al. 2002), precipitation (Xian et al. 2005), ion exchange (Carmona et al. 2006). However, in each 
technique, there are limitations and disadvantages. Among various physicochemical processes, adsorption is a highly efficient technique which has gained considerable attention for treating phenolic compounds from aqueous streams because of initial cost, flexibility and simplicity of design, ease of operation and insensitivity to toxic pollutants (Aksu 2005). However, in water treatment the most widely used method is adsorption onto the surface of activated carbon (Rengaraj et al. 2002). Activated carbons remove many of the impurities occurring in the water and wastewater. But, because of the high cost and variable performance of carbon regeneration, single use materials are desirable (AlAsheh et al. 2003).

In recent years, special attention has been focused on the use of natural adsorbents as an alternative to replace the conventional adsorbents (Bable and Kurniawan 2003). Low cost agricultural waste such as sawdust (Jadhav and Vanjara 2004), water hyacinth (Uddin et al. 2007; Abdallah 2013), date seed (Mane et al. 2005), rice husk (Kadhim and Al-Seroury 2012), waste tea (Lutfee 2010) etc. and brown algae, black tea residue (Abdallah 2013) had been reported. These works offer the possibility to develop and identify the efficiency of various agricultural wastes as low cost adsorbent. Rice straw is an agricultural waste. The utilization of this source of biomass would help to access cheaper material for adsorption of phenol. Since the main component of rice straw is carbon, it has the potential to be used as an adsorbent. The objective of this study was to determine the efficiency of raw (untreated) rice straw and different treated (thermal and physical) rice straw as adsorbent of phenol treatments at different size ranges. Langmuir and Freundlich adsorption isotherm were also used to describe the experimental findings.

\section{Materials and methods}

\section{Sample collection}

Nearly $3 \mathrm{~kg}$ of fresh rice straw were collected from the field in a polythene bag to avoid any contamination. For all adsorption study, phenol was obtained from Merck Limited, Mumbai $(M=94.11 \mathrm{~g} / \mathrm{mol})$. Stock solution of 200,00 ppm of phenol was prepared by dissolving $0.2 \mathrm{~g}$ of phenol in $10 \mathrm{ml}$ in distilled water. The stock solution was further diluted with distilled water to prepare test solution of phenol.

\section{Preparation of adsorbents}

Rice straws were thoroughly washed, cut into small pieces and initially dried in oven at about $70{ }^{\circ} \mathrm{C}$. Then grounded to small particles and sieved to separate $<1$ and $1 \mathrm{~mm}$ particles. Both sizes of particles were preserved in two separate air tight jars in a dry place.

\section{Physical activation}

For physical activation, $<1$ and $1 \mathrm{~mm}$ rice straw particles were boiled in distilled water for $2 \mathrm{~h}$. The treated samples were dried at $105{ }^{\circ} \mathrm{C}$ until constant weight and preserved in desiccators.

\section{Thermal activation}

For thermal activation, 1 and $<1 \mathrm{~mm}$ rice straw particles were taken in two ceramic crucible and heated in an oven in available high temperature of $230{ }^{\circ} \mathrm{C}$ for $3 \mathrm{~h}$, separately. After $3 \mathrm{~h}$ of heating rice straw particles were turned into ash and sieved again to separate $<1$ and $1 \mathrm{~mm}$ particles. Both sizes of particles were preserved in desiccator until experiment.
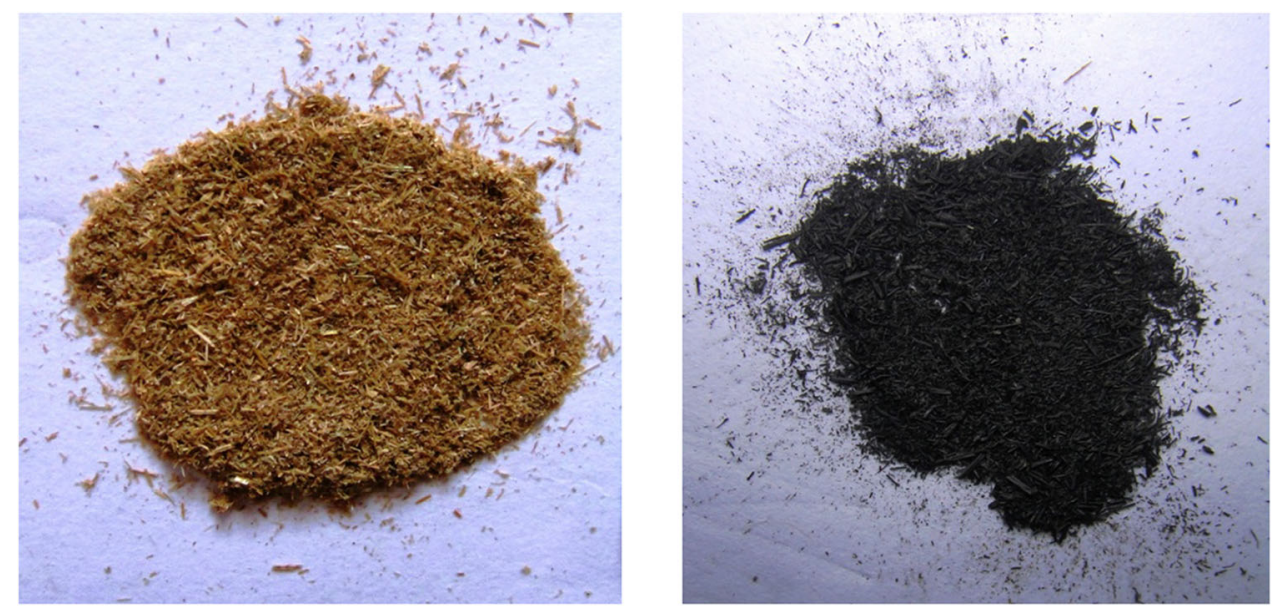

Photograph of raw rice straw and thermally activated rice straw. 


\section{Phenol adsorption study}

The study was carried out on laboratory scale by the liquid phase batch adsorption method to estimate the adsorption capacity of different adsorbents (raw rice straw, physically and thermally treated rice straw). About $0.5,1.0,1.5,2.0$ and $2.5 \mathrm{~g}$ of adsorbents were added separately to $100 \mathrm{ml}$ of phenol $(100 \mathrm{ppm})$ in different flasks, the flasks were placed in a shaker for $24 \mathrm{~h}$ at $120 \mathrm{rpm}$ at room temperature, so that the phenol may come in contact with the adsorbent sites. Sample was withdrawn from the shaker at $30 \mathrm{~min}, 1,2,3,4$ and $24 \mathrm{~h}$ time intervals, to measure the residual concentrations of phenol at different time interval and equilibrium time using UV-Visible Spectrophotometer. Effect of different amount of adsorbent dosages (0.5, 1.0, 1.5, 2.0 and $2.5 \mathrm{~g}$ ) of each type of adsorbents (raw rice straw, physically and thermally treated rice straw) were also analyzed. All studies were carried out in duplicates and average values were used for further calculations. Two control flasks, one containing $100 \mathrm{ml} 100 \mathrm{ppm}$ phenol solutions and another containing $100 \mathrm{ml}$ water, were also placed with every batch to detect loss of phenol (by volatilization or adsorption onto the walls of container) and to eliminate the effect of adsorbent color produced during experiment, respectively.

\section{Phenol assay procedure}

Phenol concentration was determined by using the 4-aminoantipyrine colorimetric method based on the procedure detailed in Standard Methods for the Examination of Water and Wastewater (APHA 1998). $0.5 \mathrm{~N} \mathrm{NH}_{4} \mathrm{OH}$ was added and mixed well. The $\mathrm{pH}$ was adjusted to $7.9 \pm 0.1$ by adding potassium phosphate buffer $(\mathrm{pH} 6.8)$ followed by adding 4-aminoantipyrine $(2 \% \quad w / v)$ and potassium ferricyanide $(8 \%, w / v)$. Samples were allowed to complete reaction at room temperature for $15 \mathrm{~min}$ and the absorbance was measured at $500 \mathrm{~nm}$ using single beam UV-Vis Spectrophotometer. A standard calibration curve was prepared to determine phenol concentration using corresponding absorbance recorded from spectrophotometer.

\section{Efficiency analysis of adsorbents}

The percentage removal of phenol and equilibrium adsorption uptake, $q_{\mathrm{e}}(\mathrm{mg} / \mathrm{g})$, was calculated by using the following relationships (Denizli et al. 2005):
$\%$ Removal Efficiency $=\frac{\left(C_{\mathrm{o}}-C_{\mathrm{e}}\right) 100}{C_{\mathrm{o}}}$

Amount Adsorbed $\left(q_{\mathrm{e}}\right)=\frac{\left(C_{\mathrm{o}}-C_{\mathrm{e}}\right) V}{W}$

( $\mathrm{mg}$ of adsorbate/g of adsorbent)

where $C_{\mathrm{o}}$ is the initial phenol concentration $(\mathrm{mg} / \mathrm{L}) ; C_{\mathrm{e}}$ is the equilibrium concentration $(\mathrm{mg} / \mathrm{L}) ; V$ is the volume of the solution (l) and $W$ is the mass of dry adsorbent $(\mathrm{g})$.

\section{Adsorption isotherm}

The constant-temperature equilibrium relationship between the quantity of adsorbate per unit of adsorbent $\left(q_{\mathrm{e}}\right)$ and its equilibrium solution concentration $\left(C_{\mathrm{e}}\right)$ is called the adsorption isotherm. A mass balance states the obvious fact that the amount of solute that adsorbed onto the solid must equal the amount of solute removed from the solution, or, in mathematical terms:

$q W=V\left(C_{\mathrm{o}}-C_{\mathrm{e}}\right)$

where $\mathrm{W}$ grams of carbon; $V$ liters of solution; $C_{\mathrm{o}}$ and $C_{\mathrm{e}}=\mathrm{mg}$ solute/liter of solution at initial and equilibrium; $q=\mathrm{g}$ solute adsorbed/g of carbon. Any consistent set of units for the quantities in this mass balance is acceptable (Cooney 1998). Thus, both sides of the mass balance represents amounts of solute ( $\mathrm{g}$, in this case). According to this mass balance, adsorption isotherms were developed by using different adsorbent doses to achieve different value of $C_{\mathrm{e}}$ (Mandi et al. 2009).

\section{Results and discussion}

\section{Effect of different adsorbents}

Phenol removal efficiency of different selected adsorbents with increasing adsorbent dosage is presented in Fig. 1 and Table 1. For both particle sizes, phenol adsorption capacity observed to increase in the order of, thermally treated (ash) $>$ physically treated $>$ raw rice straw. Ash of $<1 \mathrm{~mm}$ rice straw particles showed the highest phenol removal efficiency of $84.07 \%$ for $2.5 \mathrm{~g}$ adsorbent dose at equilibrium among all types of adsorbent studied. Thermal treatment (ashing) of raw rice straw destructs the organic matrix that causes an increase in the surface area for adsorption of phenol. Various studies reported that ashing of natural products increase adsorption capacity (Kermani et al. 2006; Maleki et al. 2010). Activated carbon prepared from palm oil mill effluent (POME- the voluminous liquid waste that 
Fig. 1 Effect adsorbent dosage on the percentage removal of phenol for different adsorbents. Contact time $=24 \mathrm{~h}$

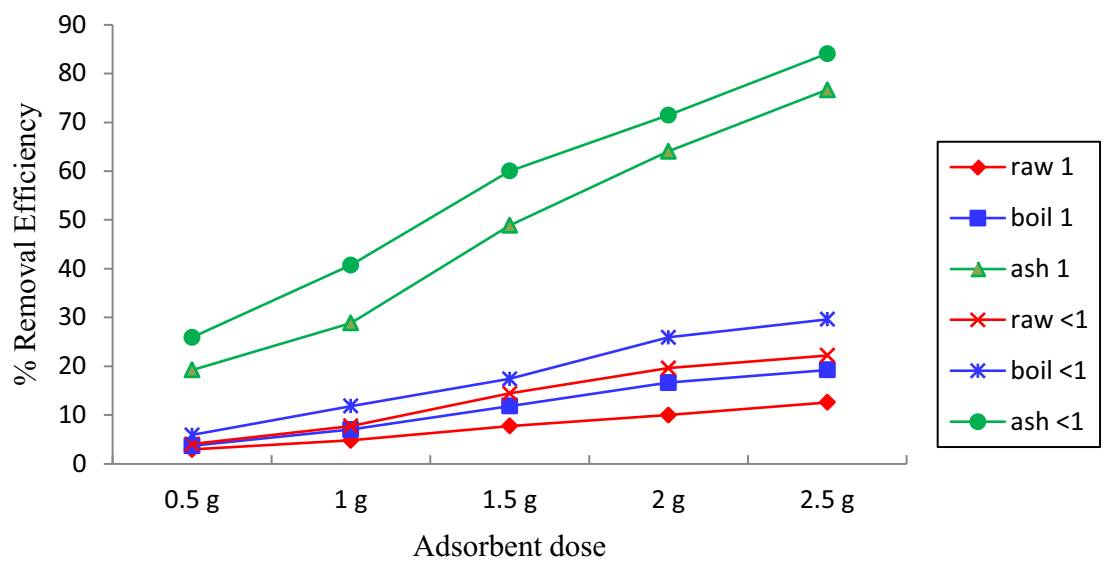

Table 1 Percentage removal of phenol with different adsorbent dosage for different adsorbents

\begin{tabular}{|c|c|c|c|c|c|c|}
\hline \multirow[t]{2}{*}{ Size of particle } & \multirow[t]{2}{*}{ Adsorbent type } & \multicolumn{5}{|l|}{ Dose range } \\
\hline & & $2.5 \mathrm{~g}(\%)$ & $2.0 \mathrm{~g}(\%)$ & $1.5 \mathrm{~g}(\%)$ & $1.0 \mathrm{~g}(\%)$ & $0.5 \mathrm{~g}(\%)$ \\
\hline \multirow[t]{3}{*}{$1 \mathrm{~mm}$} & Raw & $12.59 \pm 3.42$ & $10.0 \pm 2.75$ & $7.78 \pm 3.71$ & $4.81 \pm 3.91$ & $2.96 \pm 0.14$ \\
\hline & Boil & $19.26 \pm 2.25$ & $16.67 \pm 2.54$ & $11.85 \pm 2.21$ & $7.034 \pm 0.954$ & $3.70 \pm 3.64$ \\
\hline & Ash & $76.67 \pm 2.22$ & $64.07 \pm 1.25$ & $48.89 \pm 1.0$ & $29.63 \pm 2.29$ & $18.52 \pm 3.31$ \\
\hline \multirow[t]{3}{*}{$<1 \mathrm{~mm}$} & Raw & $22.22 \pm 4.59$ & $19.63 \pm 2.12$ & $14.44 \pm 3.78$ & $7.78 \pm 04.85$ & $4.07 \pm 0.70$ \\
\hline & Boil & $29.63 \pm 3.45$ & $25.93 \pm 3.33$ & $17.41 \pm 3.98$ & $11.85 \pm 2.04$ & $5.93 \pm 3.03$ \\
\hline & Ash & $84.07 \pm 2.01$ & $71.48 \pm 1.29$ & $60.0 \pm 2.91$ & $40.74 \pm 1.50$ & $25.93 \pm 3.75$ \\
\hline
\end{tabular}

comes from the sterilization and clarification processes in milling oil palm)sludge at $500{ }^{\circ} \mathrm{C}$ was found to remove $25.9 \%$ of phenol from an initial concentration of $50 \mathrm{mg} / \mathrm{L}$ (Alam et al. 2006). Activated carbon derived from oil palm empty-fruit bunches at $300{ }^{\circ} \mathrm{C}$ reduced the phenol concentration by $27.8 \%$ (Alam et al. 2007).

\section{Effect of particle sizes}

Results (Fig. 1; Table 1) indicate that among all three types of adsorbent as raw rice straw, physically and thermally treated rice straw, $<1 \mathrm{~mm}$ size particles had higher phenol removal efficiency than $1 \mathrm{~mm}$ size particles. For $1 \mathrm{~mm}$ particles, percentage of phenol removal for rice straw ash was $76.67 \%$ for $2.5 \mathrm{~g}$ adsorbent dose. On the other hand, phenol removal efficiencies for 1 and $<1 \mathrm{~mm}$ raw rice straw were 12.59 and $22.22 \%$.

\section{Effect of adsorbent dosages}

Five different adsorbent dosages (0.5, 1, 1.5, 2 and $2.5 \mathrm{~g}$ ) were studied for removal of phenol at a fixed initial concentration of $100 \mathrm{ppm}$. Adsorbent dosage play significant role in percentage of phenol removal. It was clearly evident from the results that a gradual increase in the adsorbent dose leads to high percentages of phenol removal. For each type of adsorbents, adsorbent dose of $2.5 \mathrm{~g}$ showed highest phenol removal capacity. Whereas, phenol removal efficiency was negligible for $0.5 \mathrm{~g}$ adsorbent dose. This may be due to increased adsorbent surface area and availability of more adsorption sites resulting from the increased adsorbent dosage. This factor contributes for greater efficiency of phenol removal. Increase in phenol removal efficiency with an increase in adsorbent dosage was also observed by Nagda et al. (2007). Some studies showed that with an increase in adsorbent mass the amount of phenol adsorbed per gram of adsorbent decreases slightly. This may be due to the aggregation of adsorbent particles that leads to a decrease in effective surface area of adsorbent available for adsorption (Mane et al. 2005). So, removal efficiency increases up to optimum dosage beyond which removal efficiency decreases. This indicates that phenol removal was effective in the dose ranges studied.

\section{Effect of contact time}

Figure 2 shows effect of contact time on the percentage removal of phenol using $2 \mathrm{~g}$ each of 1 and $<1 \mathrm{~mm}$ raw, physically (boil) and thermally (ash) treated rice straw. In case of thermally treated rice straw percentage removal of phenol was highest at any contact time. The optimal contact time required to attain equilibrium with 1 and $<1 \mathrm{~mm}$ raw rice straw and physically treated rice straw were experimentally found to be $24 \mathrm{~h}$ and with 1 and $<1 \mathrm{~mm}$ thermally 
Fig. 2 Effect of contact time on percentage removal efficiency of phenol by different adsorbents. Adsorbent dose $=2 \mathrm{~g} / 100 \mathrm{ml}$

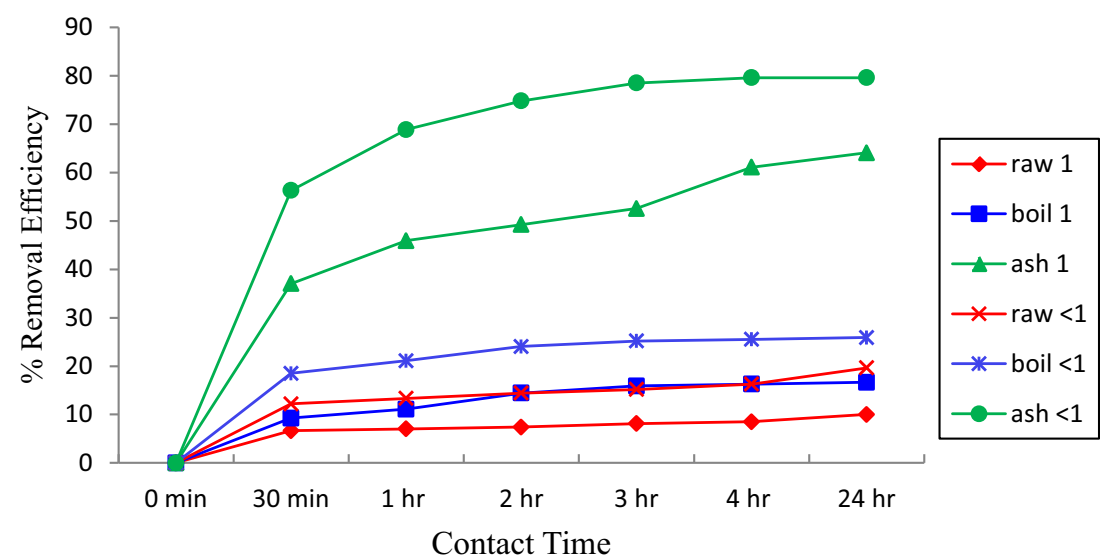

(a) Langmuir Isotherm

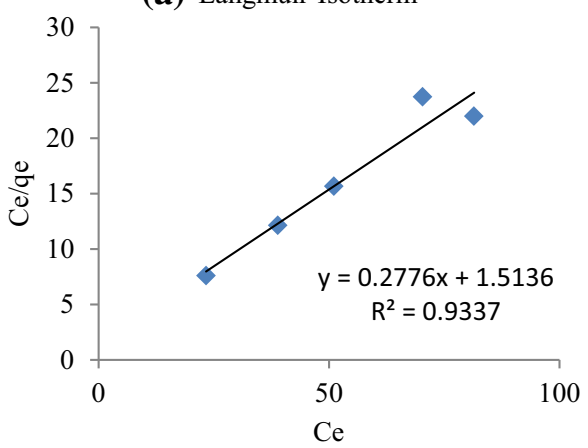

(b) Freundlich Isotherm

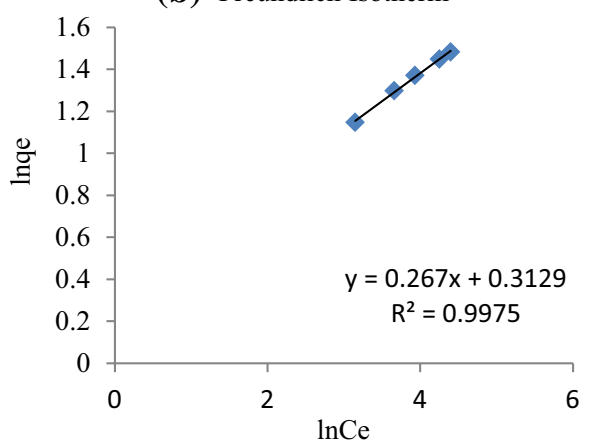

Fig. 3 a Langmuir and b Freundlich adsorption isotherm for $1 \mathrm{~mm}$ size particles of thermally (ash) treated rice straw treated rice straw were more than $24 \mathrm{~h}$. No remarkable improvement was observed after longer contact time. It was evident from the experimental results that the percentage removal of phenol increases with increase of contact time till equilibrium is attained. Maximum removal of phenol found to occur in the first $1 \mathrm{~h}$ and thereafter the sorption rate was found to decrease. The higher sorption rate at the initial period maybe attained due to an increased number of vacant sites on the adsorbent were available at the initial stage.

\section{Adsorption isotherms}

Langmuir equation,

$$
C_{\mathrm{e}} / q_{\mathrm{e}}=1 / b q_{\max }+C_{\mathrm{e}} / q_{\max }
$$

where $b$ and $q_{\max }$ are constants and $q_{\mathrm{e}}$ and $C_{\mathrm{e}}$ are as defined earlier, has a firm theoretical basis. A plot of $C_{\mathrm{oe}} / r_{\mathrm{e}}$ vs. $C_{\mathrm{e}}$ will yield a straight line of slope $1 / q_{\max }$ and intercept $1 / b q_{\max }$. Knowing values for slope and intercept allows to easily calculate values of two parameters $b$ and $q_{\max }$ (Cooney 1998).

The linearized equation for Freundlich equation as follows:

$\ln q_{\mathrm{e}}=\ln K+1 / n \ln C_{\mathrm{e}}$

The parameters $q_{\mathrm{e}}$ (with units of mass adsorbate/mass adsorbent, or mole adsorbate/mass adsorbent) and $C_{\mathrm{e}}$ (with units of mass/volume, or moles/volume) are the equilibrium surface and solution concentrations, respectively. A plot of $\ln q_{\mathrm{e}}$ vs. $\ln C_{\mathrm{e}}$ will yield a straight line of slope $\ln K$ and intercept $1 / n$. Knowing values for slope and intercept allows to easily calculate values of two parameters $K$ and $n$ (Cooney 1998).

Langmuir and Freundlich adsorption isotherm were developed for 1 and $<1 \mathrm{~mm}$ size particle of thermally (ash) treated rice straw. Langmuir and Freundlich adsorption isotherm were developed for 1 and $<1 \mathrm{~mm}$ size particle of thermally (ash) rice straw as presented in Figs. 3 and 4, respectively. Isotherm parameters were calculated from graph and presented in Table 2. Regression coefficients show that $<1 \mathrm{~mm}$ size thermally (ash) treated rice straw have less fit with Freundlich isotherm. The Freundlich adsorption capacity for $1 \mathrm{~mm}$ size particle was $4.54 \mathrm{mg} / \mathrm{g}$. From the magnitude of the gradients of the lines, it can be said that adsorption intensity of phenol on $1 \mathrm{~mm}$ size particle is less than the $<1 \mathrm{~mm}$ size particles. This observation may be related to the surface chemistry of the adsorbent materials which is dependent on the natural variability in the composition of the cellulosic carbon precursors. The Langmuir constant $q_{\text {max }}$, which is a measure of the maximum sorption capacity corresponding to complete monolayer coverage. The maximum sorption capacity for 1 and $<1 \mathrm{~mm}$ size particles were 3.745 and $5.780 \mathrm{mg} / \mathrm{g}$, respectively. 
Fig. 4 a Langmuir and b Freundlich adsorption isotherm for $<1 \mathrm{~mm}$ size particles of thermally (ash) treated rice straw (a) Langmuir Isotherm

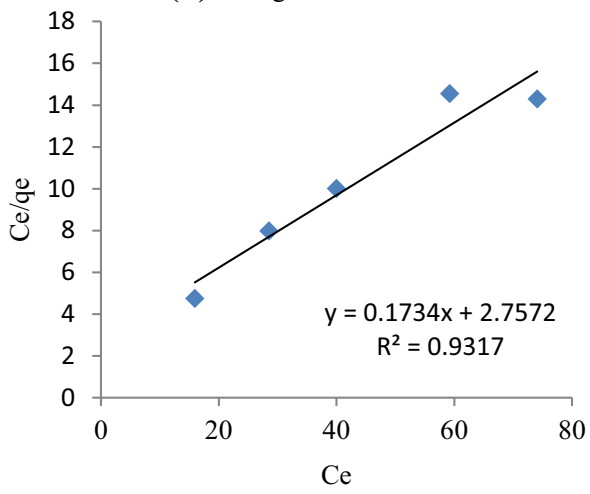

(b) Freundlich Isotherm

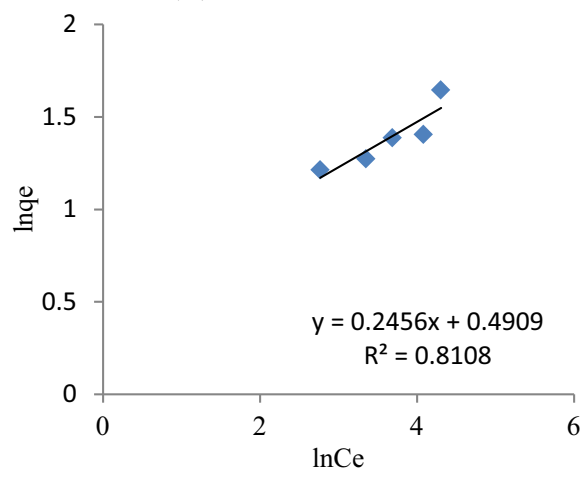

Table 2 Parameters of Langmuir and Freundlich adsorption isotherm model

\begin{tabular}{|c|c|c|c|c|c|c|}
\hline \multirow{2}{*}{$\begin{array}{l}\text { Particle } \\
\text { size }\end{array}$} & \multicolumn{3}{|l|}{ Langmuir constants } & \multicolumn{3}{|l|}{ Freundlich } \\
\hline & $\begin{array}{l}\text { Maximum sorption capacity } \\
q_{\max }(\mathrm{mg} / \mathrm{g})\end{array}$ & $\begin{array}{l}\text { Adsorption/ } \\
\text { Desorption energy } b\end{array}$ & $\begin{array}{l}\text { Regression } \\
\text { coefficient, } R^{2}\end{array}$ & $\begin{array}{l}\text { Adsorption capacity, } \\
K(\mathrm{mg} / \mathrm{g})\end{array}$ & $\begin{array}{l}\text { Intensity of } \\
\text { adsorption, } n\end{array}$ & $\begin{array}{l}\text { Regression } \\
\text { coefficient, } R^{2}\end{array}$ \\
\hline $1 \mathrm{~mm}$ & 3.745 & 0.856 & 0.933 & 4.540 & 3.610 & 0.997 \\
\hline$<1 \mathrm{~mm}$ & 5.780 & 0.063 & 0.931 & 1.6323 & 4.082 & 0.810 \\
\hline
\end{tabular}

\section{Conclusion}

It was found that phenol removal efficiency for 1 and $<1 \mathrm{~mm}$ size particles ranges vary significantly for various types of treated and raw rice straw. For same type of treatment the removal efficiency is much higher for $<1 \mathrm{~mm}$ particle size range. Phenol removal efficiency attained by thermally treated rice straw (ash) was highest among the all tested adsorbents. Removal efficiency was lowest for raw rice straw. Physical activation through boiling slightly increases the removal efficiency. The removal efficiency increase in the order of, thermally treated (ash) $>$ physically treated $>$ raw rice straw. Removal efficiencies of raw rice straw and boiled rice straw were not significant but clearly higher for $<1 \mathrm{~mm}$ particles. Freundlich isotherm best fit the equilibrium data for $1 \mathrm{~mm}$ thermally treated rice straw. The results obtained in this study suggested that thermally treated rice straw (ash) has the potential to be developed as adsorbent for removal of phenol from aqueous solution.

Open Access This article is distributed under the terms of the Creative Commons Attribution 4.0 International License (http:// creativecommons.org/licenses/by/4.0/), which permits unrestricted use, distribution, and reproduction in any medium, provided you give appropriate credit to the original author(s) and the source, provide a link to the Creative Commons license, and indicate if changes were made.

\section{References}

Abdallah MAM (2013) The potential of different bio adsorbents for removing phenol from its aqueous solution. Environ Monit Assess 185:6495-6503

Aksu Z (2005) Application of biosorption for the removal of organic pollutants: a review. Process Biochem 40:997-1026

Alam MZ, Muyibi SA, Mansor MF, Wahid R (2006) Removal of phenol by activated carbons prepared from palm oil mill effluent sludge. J Env Sci 18:446-452

Alam MZ, Muyibi SA, Mansor MF, Wahid R (2007) Activated carbons derived from oil palm empty-fruit bunches: application to environmental problems. J Env Sci 19:103-108

Al-Asheh S, Banat F, Abu-Aitah L (2003) Adsorption of phenol using different types of activated bentonites. Sep Purif Technol 33:1-10

APHA (1998) Standard methods for the examination of water and wastewater, 20th edn. AWWA-APHA-WEF, Washington, DC

Bable S, Kurniawan TA (2003) Low-cost adsorbent for heavy metals uptake for contaminated water: a review. J Hazard Mater 97:219-243

Banat FA, Al-Bashir B, Al-Asheh S, Hayajneh O (2000) Adsorption of phenol by bentonite. Env Poll 107:391-398

Carmona M, De Lucas A, Valverde JL, Velasco B, Rodriguez JF (2006) Combined adsorption and ion exchange equilibrium of phenol on Amberlite IRA-420. Chem Eng J 117:155-160

Cooney DO (1998) Adsorption design for wastewater treatment. Lewis Publishers, Washington, DC

Denizli A, Cihangir N, Ttizmen N, Alsancak G (2005) Removal of chlorophenols from aquatic systems using the dried and dead fungus Pleurotussajorcaju. Bioresour Technol 96:59-62

Jadhav DN, Vanjara AK (2004) Removal of phenol from wastewater using sawdust, polymerized sawdust and sawdust carbon. Indian J Chem Technol 11:35-41 
Kadhim F, Al-Seroury FA (2012) Characterization the removal of phenol from aqueous solution in fluidized bed column by rice husk adsorbent. Res J Recent Sci 1:145-151

Kermani M, Pourmoghaddas H, Bina B, Khazaei Z (2006) Removal of phenol from aqueous solutions by rice husk ash and activated carbon. Pak J Biol Sci 9:1905-1910

Knop A, Pilato LA (1985) Phenolic resins-chemistry: applications and performance. Spinger, Berlin

Lutfee AT (2010) Removal of phenol from aqueous solution by agricultural waste. Eng Tech J 28:5938-5955

Mahvi AH, Maleki A, Eslami A (2004) Potential of rice husk and rice husk ash for phenol removal in aqueous systems. Am J Appl Sci $1: 321-326$

Maleki A, Mahvi AH, Ebrahimi R, Khan J (2010) Evalution of barley and its ash in removal of phenol from aqueous system. World Appl Sci J 8:369-373

Mandi L, Achak M, Hafidi A, Ouazzani N (2009) Low cost biosorbent for the removal of phenolic compounds from olive mill wastewater. Options Méditerranéennes A n88:179-186

Mane SM, Vanjara AK, Sawant MR (2005) Removal of phenol from wastewater using date seed carbon. J Chin Chem Soc 52:1117-1122
Nagda GK, Diwan AM, Ghole VS (2007) Potential of tendu leaf refuse for phenol removal in aqueous systems. Appl Ecol Env Res 5:1-9

Ozbelge TA, Ozbeze OH, Baskaya SZ (2002) Removal of phenolic compounds from rubber-textile wastewaters by physic-chemical methods. Chem Eng Process 41:719-730

Rengaraj S, Moon SH, Sivabalan R, Arabindoo B, Murugesan V (2002) Agricultural solid waste for the removal of organics: adsorption of phenol from water and wastewater by palm seed coat activated carbon. Waste Manag 22:543-548

Roostaei N, Tezel FH (2004) Removal of phenol from aqueous solution by adsorption. J Env Manag 70:157-164

Uddin MT, Islam MS, Abedin MZ (2007) Adsorption of phenol from aqueous solution by water hyacinth ash. J Eng Appl Sci 2:11-17

WHO (1994) IPCS Environmental Health Criteria for Phenol (161). In: First draft prepared by Ms G.K. Montizan. WHO, Finland

Wu C, Liu X, Wei D, Fan J, Wang L (2001) Photosonochemical degradation of phenol in waret. Water Res 35:3927-3933

Xian X, He P, Jin J, Ho Z (2005) Study on Us/O3 mechanism in pentachlorophenol decomposition. J Zhejiang Univ Sci 6:569-573 